\title{
A Comparison of the Problem-solving Skills of Students in PjBL Versus CPjBL Model: An Experimental Study
}

\author{
Nizwardi Jalinus $^{1}$, Syahril ${ }^{2 *}$ \& Rahmat Azis Nabawi ${ }^{3}$ \\ ${ }^{1}$ Universitas Negeri Padang, Jl. Prof. Dr. Hamka Kampus UNP Air Tawar, Padang, 25131, INDONESIA \\ ${ }^{2 *}$ Universitas Negeri Padang, Jl. Prof. Dr. Hamka Kampus UNP Air Tawar, Padang, 25131, INDONESIA \\ ${ }^{3}$ Universitas Negeri Padang, J1. Prof. Dr. Hamka Kampus UNP Air Tawar, Padang, 25131, INDONESIA
}

DOI: https://doi.org/10.30880/jtet.2019.11.01.005

Received $30^{\text {th }}$ August 2018; Accepted $18^{\text {th }}$ November 2018; Available online $31^{\text {st }}$ March 2019

\begin{abstract}
Each learning model has different pattern and approach that will affect the learning outcomes. Thus, a study is required focused on the effect of implementing the learning model so that it can become a reference for teachers. The study aimed to compare the students' problem-solving skills using Project Based Learning (PjBL) model and Cooperative-Project Based Learning (CPjBL) model implementation. The study was carried using out a quasi-experiment method. To reveal problem-solving skills, students used the authentic Assessment technique. A ttest was used to analyse data. The results of the study showed that there is a significant difference in students' problem-solving skills between the PjBL and the CPjBL model, and that these differences are strongly influenced by the syntax or stages of the instructional model. Results show that CPjBL is more effective to improve students' problem-solving skills. In $\mathrm{PjBL}$ model, learning activities are directed to project assignment, while in $\mathrm{CPjBL}$ model, learning activities of students began with motivation to achieve the learning outcomes, which were provided by modules through cooperative learning, understanding the concept and work principles through instructional media, prototype, discussion and demonstration. The cooperative learning made students group learning more structured corresponded with learning topic assigned. The students' group would continue to carry out project assignment with permanent members and learning topic. The CPjBL model is more superior than PjBL model in accordance with the ability of the students as the syntax of the model is systematically organized based on learning hierarchy.
\end{abstract}

Keywords: Problem-solving skills; project-based learning; cooperative learning; cooperative-project based learning

\section{Introduction}

Learning in vocational education is not similar to learning in general education. The difference between learning in vocational education and general education is viewed as a function of learning method, in that general education tends to provide more illustration, information, and simulation, while learning activity in vocational education involves more practical work and learning by doing. This means that vocational education learning does not explain much theory of learning material, as students are instructed to carry out the concept, principle, designing or making products. The student in vocational education will learn how to apply theory to practice as a product of learning which they learn individually (Prosser and Ouigley, 1950). To be able to create learning that is in accordance with the learning characteristics of vocational education, the teacher must be selective in choosing a learning model, because each learning model that is implemented will have a different impact on student competence.

Every activity in the future work world will encounter various problems that must be solved, therefore problemsolving skill must be mastered by vocational education graduates. Mohamed and Omar (2010) mentioned that one of 
skills required of graduates by industry was problem-solving skill. Kamdi (2011) stated that the best learning in terms of good vocational education is creating a learning environment based on activities that provide an opportunity for students to apply their knowledge to solve practice problems and to better understand and utilize technology. Vocational education provides an opportunity for students to learn how to solve problems. Smaldino et al. (2012) discussed that in solving problems of the real world, students can obtain the knowledge and skill that they will need after they graduate. Learning activity that gives an opportunity for students to learn solving problem can support students to use their knowledge to investigate how problems occur and how to solve them so that students obtain new knowledge and also strengthen the knowledge that they already have (Merrill, 2002; Yeen-ju, et al., 2015). Problem solving skill has become an important skill that must be mastered by graduates of vocational education, because when they work, they will meet many problems.

This article aims to compare and discuss differentiation of problem-solving skill students between the implementation of $\mathrm{CPjBL}$ and $\mathrm{PjBL}$ on conversion energy course. Project-based learning is a learning activity that conditions student learning activities in the execution of project tasks that are lifted from the real world. CPjBL, in contrast, is a combination learning model from cooperative learning and project-based learning, where at the beginning of learning, students learn by cooperative learning to learn about the design of a product through the study of papers, books, or thesis and then students learn to carry out project tasks that are lifted from the real world.

\subsection{Project Based Learning}

Learning model that provides an opportunity for students to carry out project assignment and learning theory on a model that embraces constructivism learning theory is known as project-based learning. Project based learning is considered as learning that directs students to solve real world problems or their world challenges through a long process of investigation (Lattimer and Riordan, 2011). The project-based learning model is learning with constructivism principle where the learner uses knowledge and skill competence in looking for a solution to solve a practice problem (Arcidiacono et al., 2016). Project based learning has a wide implementation space in the teaching of vocational education (Zhang, 2013).

In a project-based learning model, students require the opportunity to apply their knowledge and skill to solve structure problem in a project carried out either individually or in group (Ng et al., 2016). Students' attitudes, knowledge and skills were developed in a learning activity with the implementation of project-based learning model. Students learnt from project assignment of the real-world problem and project activity step that is given to students was adopted from the real work of industry (Jalinus and Nabawi, 2018). Project-based learning model instils motivation and project assignment understanding of the real world as the basis of the project task students (Balve and Albert, 2015). The emotional and psychomotor skills of students also develop with the implementation of project-based learning (Baran et al., 2018). Project based learning not only fulfills the philosophy of teaching vocational education, but also makes students the center of the teaching and learning process, and makes them gain more knowledge and skills (Xinyan, 2016).

\subsection{Cooperative-Project Based Learning}

Various studies had been conducted to developed project-based learning in combination with other methods. Nepal and Jenkins (2011) explained about combination of project based learning and traditional learning (Lectures-tutorial-based teaching) for engineering design course, and the result from the study showed that the blended approach, designed appropriately, helps to minimize the problem of both approaches. Mohamed et al., (2011), in a study focused on implementation of Project Oriented Problem Based Learning (POPBL) for analog electronics (BEL10203) course at the Faculty of Electrical and Electronics Engineering-UTHM. The project of students were assignment about designing an electronic circuit, provided students with the experience of individual learning process, where students do not only learn how to carry out of project until it finished, but they also learn how to work in group and be leader in a work group. Ana and Nurlaela (2012) developed model Patisserie Project-Based Learning (P2BL), and the fundamental concept of this model is the importance of equipping students with problem-solving skills, divergent thinking, creativity and collaborative teamwork skill. Vila et al. (2017) carried out study about project-based learning collaborative engineering learning to develop industry 4.0 skills with a Product Lifecycle Management (PLM) framework. This result of the study explained how project based learning is proposed as a learning approach suitable to provide a learning experience that facilities development of industry 4.0 skill and competences.

In learning designed to improve and develop competence, students need to learn together in a group work that is interconnected with fellow students. Learning activities that condition students to learn together is known as cooperative learning. Siegel (2005) states that cooperative learning is a learning that conditioned some students in a study group to support each other in improving and developing their competence. Many engineering schools in the world recommend that cooperative learning be applied to learning activities because it has proven effective in higher education (Johnson and Johnson, 1999). The purpose of cooperative learning is to promote effective learning within and outside the classroom, through group learning activities (Azizan, 2018). The combination of cooperative and project-based learning is very suitable to learning in vocational education because project-based learning leads the 
students to construct their knowledge in designing a tool or machine to solve real-world problems, and the learning activities required cooperation so that learning can be implemented effectively. Perez et al. (2009) suggests that in learning implemented using cooperative project-based learning, students learn together, become integrated and interconnected and participate in project tasks to develop their ability to design real machines. Chen (2004) explains that students would have a good academic achievement if cooperative project-based learning was applied in students learning assignment about web page development. Through cooperative project-based learning, the students have high motivation so that they are able to achieve better learning outcomes (Tafakur and Suyanto, 2015).

\section{Methodology}

The study of the quasi-experiment method used the two-group research design focused on energy conversion course in Diploma III of Vocational Education (3-years) in Mechanical Engineering Department - Fakultas Teknik - Universitas Negeri Padang, Indonesia. The population of the research included 40 students, with a group of 20 students as control group conducting PjBL model and another group of 20 students treated as experiment group by using CPjBL model of learning.

The difference in treatment of the two groups lies in the syntax used. Eggen and Kouchack (2012) define syntax or procedures as stages that assist students to reach a learning goal. The syntax of both models can be seen in Table 1 . In the classroom, control learning activities with the implementation of model PjB1 using Syntax of the Kamdi (2010) include seven stages of learning activities. In the experimental class, the learning activities were carried out by implementing the $\mathrm{CPjBL}$ model with ten stages of learning. This $\mathrm{CPjBL}$ model has been validated by experts with Aiken coefficient of 0.917 and this model is reliable to be implemented in vocational education. In the syntax of PjBL model, the students directly carry out the project task. The syntax of the $\mathrm{CPjBL}$ model, in contrast, requires that students learn the concept of teaching materials (through modules, articles, theses, prototype media and video learning) with the implementation of cooperative learning model and then the students carry out project tasks in the learning activities through implementation of the project-based learning model. In this case, it can be seen that the difference between the learning activities in the PjBL and CPjBL models is at the learning stage.

Tabel 1 - Difference in PjBL and CPjBL model syntax implemented at conversion energy course

\begin{tabular}{|c|c|c|c|}
\hline \multicolumn{2}{|r|}{ Control Class } & \multicolumn{2}{|r|}{ Experiment Class } \\
\hline Stage & PjBL (Kamdi, 2010) & Stage & CPjBL \\
\hline 1 & $\begin{array}{l}\text { Determination of project theme by } \\
\text { teacher and students }\end{array}$ & 1 & The formulation of the expected learning outcome \\
\hline 2 & Division of students group work & 2 & Understanding the concept of teaching material \\
\hline 3 & $\begin{array}{l}\text { Observation and identification of } \\
\text { various problems }\end{array}$ & 3 & Demonstration prototype media and video learning \\
\hline 4 & Preparation of project proposal & 4 & $\begin{array}{l}\text { Project assignment (students are assigned to identify } \\
\text { problems from the real-world as the basis of the project } \\
\text { and relevant to the course) }\end{array}$ \\
\hline 5 & Production process & 5 & Approval of the student's project plan \\
\hline 6 & $\begin{array}{l}\text { Assessment of process or product } \\
\text { and feedback of students work } \\
\text { method }\end{array}$ & 6 & Working on the project proposal \\
\hline \multirow[t]{4}{*}{7} & Presentation of project report & 7 & Progress check of the project proposal \\
\hline & & 8 & $\begin{array}{l}\text { Analyse, design and create detailed design engineering } \\
\text { (blueprint) of the project }\end{array}$ \\
\hline & & 9 & $\begin{array}{l}\text { Progress check of the analysis design and create } \\
\text { detailed design engineering of the students' project }\end{array}$ \\
\hline & & 10 & Presentation of the project report \\
\hline
\end{tabular}

Assessment of students' problem-solving skill is carried out by using authentic assessment. Observers assess their students' problem-solving skill using a range score of 1 to 5 . The instrument used to assess the students' problemsolving skills is shown in table 2. Students' problem-solving skills are seen from 5 aspects, including identification skills, ability to form problems that have been identified, the ability to develop strategies, problems, and performance that create problems that can solve real world problems. 
Table 2 - Instrument of the assessment of students' problem-solving skills

\begin{tabular}{clc}
\hline No. & \multicolumn{1}{c}{ Aspect } & Score (1 - 5) \\
\hline 1 & The skill to identify what elements must be understood about the real problem & \\
2 & The skill to formulate the problem that has been identified \\
3 & The skill to determine strategy or right stages to solve a real problem \\
4 & The skill to interpret data of the real problem \\
5 & The skill to solve the problem using a project assignment \\
\hline
\end{tabular}

Before carrying out a comparison analysis of students' problem-solving skills, analysis of requirement test, normality and variance homogeneity test must be carried out. The test data analysis in this experiment research uses Ttest to compare the problem-solving skill of students' of both the experiment and control treatment groups. This is done in order to prove the hypothesis that there is a significant difference of problem-solving skills of both groups after treatment of PjBL and CPjBL, as indicated from sig. (2-Tailed) less than 0.05.

\section{Result}

\subsection{Analysis Requirement Test}

Normality test is carried out using Kolmogorov-Smirnov with significant level of $>0.05$. The result of the test can be seen in Table 3.

Table 3 - Normality and Homogeneous test of problem-solving skill students

\begin{tabular}{|c|c|c|c|c|c|c|c|}
\hline \multirow[b]{2}{*}{ No. } & \multirow[b]{2}{*}{ Problem solving skills } & \multicolumn{2}{|c|}{ PjBL } & \multicolumn{2}{|c|}{ CPjBL } & \multirow[b]{2}{*}{$\begin{array}{l}\text { Levene } \\
\text { Statistic }\end{array}$} & \multirow[b]{2}{*}{ Sig. } \\
\hline & & $\begin{array}{l}\text { Sample K- } \\
S\end{array}$ & Sig. & $\begin{array}{l}\text { Sample K- } \\
\mathrm{S}\end{array}$ & Sig. & & \\
\hline 1 & $\begin{array}{l}\text { The skill identifies elements that } \\
\text { must be understood about real } \\
\text { problem }\end{array}$ & 1,352 & 0.052 & 1.234 & 0.095 & 0.112 & 0.740 \\
\hline 2 & $\begin{array}{l}\text { The skill to formulate the problem } \\
\text { that has been identified }\end{array}$ & 1.129 & 0.156 & 1.129 & 0.156 & 0.522 & 0.474 \\
\hline 3 & $\begin{array}{l}\text { The skill to determined strategy or } \\
\text { right stages to solve a real problem }\end{array}$ & 1.255 & 0.086 & 0.999 & 0.272 & 0.086 & 0.771 \\
\hline 4 & $\begin{array}{l}\text { The skill to interpret data of real } \\
\text { problem }\end{array}$ & 1.234 & 0.095 & 1.142 & 0.147 & 0.861 & 0.359 \\
\hline 5 & $\begin{array}{l}\text { The skill to solve problem with } \\
\text { project assignment }\end{array}$ & 1.117 & 0.125 & 1.333 & 0.057 & 0.039 & 0.844 \\
\hline & Total & 0.674 & 0.753 & 0.671 & 0.759 & 0.084 & 0.774 \\
\hline
\end{tabular}

The result of problem-solving assessment normality test in Table 3 shows the value of sig. (2-tailed) for control class is 0.704 and experiment class is 0.759 . The mean is higher than 0.05 , and both problem-solving data are distributed normally. The homogeneous test is carried out toward problem-solving assessment using Levene Statistic test with criteria said to be homogenous if significant level is greater than 0.05 . Based on Table 3 , it can be seen that significant value of problem-solving assessment is 0.500 , which is higher than 0.05 , so it can be concluded that problem-solving data obtained in this study have similar variance. Based on the results of the data prerequisite test that has been done, it can be concluded that the data obtained from the results of the research that has been carried out is feasible to be continued in the $\mathrm{T}$ test analysis.

\subsection{Comparison of Students Problem Solving Skill}

Comparison of problem-solving skills of students between the implementation of PjBL model (control class) with CPjBL (experiment class) can be identified and analysed. Based on an analysis of students problem-solving skill, overall that there is a significant difference between control class and experiment class, with Sig. (2-tailed) value of 0.000 . Seen from the perspective of five items of students' problem-solving skill, there are three significant differences and two items of students' problem-solving skills that were not significant. Three items of students problem-solving skills having sig. (2-tailed) values less than 0.05 were as follows: the skill to formulate the problem; the skill to determine the appropriate strategy or right stages to solve a real problem; and the skill to solve the problem with project assignment. Two items of students' problem-solving skill these were not significant with the sig. (2-tailed) value greater than 0.05 are as follows: the skill to identify elements that must be understood of the real problem and the skill to interpret data of the real problem. Based on the results of the T-test that has been done, it can be concluded that there is a significant difference in students' problem-solving abilities between the PjBL class and the CPjBL class. 
Table 4 - Comparisons between implemented PjBL and CPjBL model on the level of problem-solving skills on the conversion energy course

\begin{tabular}{clcccccc}
\hline \multirow{2}{*}{ No. } & \multicolumn{1}{c}{ Problem solving skills } & \multicolumn{2}{c}{ PjBL } & \multicolumn{2}{c}{ CPjBL } & \multirow{2}{*}{ T } & $\begin{array}{c}\text { Sig. (2- } \\
\text { tailed) }\end{array}$ \\
\cline { 2 - 5 } 1 & $\begin{array}{l}\text { Mean } \\
\text { The skill to identify elements that must } \\
\text { be understood about real problem }\end{array}$ & 4.25 & 0.64 & 4.30 & 0.66 & -0.244 & 0.809 \\
2 & $\begin{array}{l}\text { The skill to formulate the problem that } \\
\text { has been identified }\end{array}$ & 3.15 & 0.72 & 4.25 & 0.72 & -5.013 & 0.000 \\
3 & $\begin{array}{l}\text { The skill to determined strategy or right } \\
\text { stages to solve real problems }\end{array}$ & 3.30 & 0.75 & 4.10 & 0.79 & -3.325 & 0.002 \\
4 & 3.70 & 0.66 & 3.85 & 0.72 & -0.714 & 0.479 \\
$\begin{array}{l}\text { The skill to interpret data of real } \\
\text { problem }\end{array}$ & $\begin{array}{l}\text { The skill to solve problems with project } \\
\text { assignment }\end{array}$ & 3.80 & 0.70 & 4.40 & 0.60 & -2.924 & 0.006 \\
\hline \multicolumn{1}{c}{ Total } & 3.67 & 0.69 & 4.19 & 0.770 & -5.313 & 0.000 \\
\hline
\end{tabular}

\section{Finding and discussion}

Differentiation of students' problem-solving skill on learning activity with the implementation of PjBL model and CPjBL model are not separated from the quality of learning activity that is affected by syntax from both models. In control class with learning activity using implementation of PjBL by syntax implementation of Kamdi (2010), students carry out project assignment directly, while in the syntax of CPjBL model, students are provided competence before carrying out project assignment (see table 1). Differences in student problem-solving abilities between the results of the implementation of the PjBL and CPjBL models viewed from each aspect of the problem skills that have been assessed are discussed comprehensively in the next paragraph.

Concerning the skill to identify elements that must be understood in terms of real-world problems, there is no difference between the implementation of PjBL model and CPjBL model. However, students' average values with the implementation of CPjBL model on this aspect are slightly higher (4.30) than the implementation of PjBL model (4.25). Regarding syntax, both models provide an opportunity for students to observe, identify, and determine one of the problems that are urgent as the basis of their project assignment. It is critical that students understand the problems that exist in the real world, which gives students high motivation to solve these problems. According to Pablos and Pozo (2017), project-based learning develops research basic skills and students' critical thinking skill. There are problems with students' critical thinking skill that exist in the real world of this study. According to Saripudin et al. (2015) regarding the development of project-based learning model with student project theme about environmental management, the result of this study shows students' critical thinking skill can be developed. It can be concluded that students' ability to identify elements that must be understood of the real-world problem relate to critical thinking skill. Kim and Choi (2014) mentioned that to succeed in problem-solving, students need to develop their critical thinking skills in order to analyze the problems that appear.

Concerning the skill to formulate the problem that has been identified, there is a significant difference between both models. Students' average values of this aspect with the implementation of CPjBL is 4.25 , which is higher than students that implement $\mathrm{PjBL}$ model with value of 3.15. The formulation that is made by students is the ability to ask questions that can solve a problem that has been identified. Students problem-solving competencies of CPjBL group is stronger in this aspect because students understand and learn project that has been made by previous researchers before carrying out project assignment, and this learning activity is available on syntax the second of CPjBL model (see table 1). In this learning stage, students are divided into small groups to discuss the topic as their group assignment, write a summary, present it in front of the class and discuss it. The type of learning is known as cooperative learning. The implementation of $\mathrm{CPjBL}$ model makes students problem-solving skill superior to students who underwent implementation of PjBL model. This result corresponds with the study of Neo (2004), who declared that cooperative learning assists students to join in learning group to manage time and their project, increase communication skill and their team spirit, increase their motivation in learning, and increase their understanding about learning material. Cooperative learning teaches students to believe in teacher and have a greater believe in their ability to think, to look for information from another source, and to learn from other students (Syarifuddin, 2011). It can be taken to mean that to make the formulation of the problem, at first students must understand what will be carried out or what is a project involves so that can they can solve problems that exist in the real world. To have this competence, students must understand and learn projects that have been conducted by previous researchers.

Learning activities by implementing cooperative learning including module also affected students' abilities to determine the right strategy for solving the real-world problem. There is a significant difference between the implementation of PjBL and CPjBL model of learning. The average score of students' problem-solving skills with $\mathrm{CPjB}$ model treatment is 4.10 , which is higher than students who were treated by $\mathrm{PjBL}$ model with an average score of 
3.30. Students understood what was the right strategy or stages in solving the problem of learning activity with cooperative learning method that has been applied. Chen and Chuang (2011) argued that cooperative learning assist students to develop their problem-solving ability because they were able to share ideas, and get to know each other. This can strengthen cooperative learning to support student learning achievement. Concerning the skill aspect of data interpretation of the real problem, there is no significant difference between a class with implementation of PjBL model and class with implementation of CPjBL model. Average scores of students' ability in giving data interpretation of real problem in experiment class was 3.85 and class control was 3.70. The skill of data interpretation of the real problem is students' ability to find the meaning in the real problem.

The fifth aspect of students' problem-solving skill is the skill of solving the problem with project assignment. In this aspect, there is a significant difference between the implementation of PjBL and the CPjBL model. Average scores for implementation of $\mathrm{PjBL}$ model is 3.80, while the average score of CPjBL group is 4.40, which is higher than PJBL group. This can be taken to mean that the combination of cooperative learning and project-based learning has a great influence on the students' skill in solving a problem. The combination of both methods organizes students to learn the process by putting theory into practice, applying concept into the real problem of the project. Cooperative project-based learning is learning that integrates project-based learning that is carried out with cooperative learning strategy (Lazinica and Calafate, 2009). The study of Baser et al. (2017) recommended that implementation of cooperative project-based learning improved student's motivation to design project and to benefit them in real life.

The CPjBL model is a combination of two models of learning, which are cooperative learning and project-based learning. First, students learn to understand the theories through learning with cooperative learning. Then, students carry out project tasks with the application of project-based learning model. The treatment of cooperative learning model at the beginning of the process of learning has a great influence on the students' ability to carry out the project assignment. Students feel confident in their ability to solve various problems that appear in designing, choosing, drawing and calculating their project assignment in a group or individually. Meanwhile, students carry out their project directly in implementation PjBL model, and tend to be uncertain, doubtful, perhaps spend too much time on reading and searching for more information, in discussion in the group as well as consulting with a supervisor. When they encounter problems, they have to make a solution and need assistance by discussion and consultation with lecturer. In this case, when lecturers or teachers assist them, most of the way out is created by a teacher or lecturer. Thus, CPjBL is more effective than PjBL in the case of teaching the course of Energy Conversion. Perhaps it can be the difference if the course is a practical subject such as welding, or lathe machine practice.

\section{CONCLUSION}

Based on the result of a study that has been carried out about the comparison of students' problem-solving skill between the implementation of PjBL and CPjBL model, it can be concluded students' problem-solving skill with the implementation of $\mathrm{CPjBL}$ is superior to $\mathrm{PjBL}$ model learning activity. $\mathrm{CPjBL}$ is thus superior to PjBL in problemsolving skill, as it can organize systematic learning stage of syntax model. Before students carry out project assignment, they learn about the subject matter first through module, book, papers based on cooperative learning, so that they can solve a problem that they face easily when carrying out project assignment. There was debriefing competencies that can help students in solving problems they find when carrying out their project tasks. Combination of cooperative and project-based learning be an effective instructional model to enhance student competence.

\section{Reference}

Ana \& Nurlela, L. (2012). Development model of Patisserie Project-based Learning. Journal of Technical Education and Training, 4 (2), 30-44.

Arcidiacono, G. et al. (2016). Application of axiomatic design for project based learning methodology. Procedia CIRP, 53, 166-172. doi: 10.1016/j.procir.2016.08.003

Azizan, M. T., Mellon, N., Ramli, R.M. \& Yusup, S. (2017). Improving teamwork skills and enhancing deep learning via development of board game using cooperative learning method in reaction engineering course. Education for Chemical Engineers, (22), 1-13. doi: 10.1016/j.ece.2017.10.002

Balve, P. \& Albert, M. (2015). Project-based learning in production engineering at the Heilbronn learning factory. Proceeding of the $5^{\text {th }}$ Conference on Learning Factories 2015, Procedia CIRP, 32 (2015), 104-108. doi:10.1016/j.procir.2015.02.215

Baran, M., Maskan, A. \&Yasar, S. (2018). Learning Physics Project-based Learning Game Techniques. International Journal of Instruction, 11(2), 221-234. doi: 10.12973/iji.2018.11215a

Baser, et al. (2017). Collaborative project-based learning: an integrative science and technological education project. Research in Science \& Technological Education, DOI: 10.1080/02635143.2016.1274723 
Chen, L-L., (2004). Cooperative project-based learning and students' learning styles on web pages development. $J$. Educational Technology Systems, 32 (4), 363 - 375. doi: 10.2190/LRXX-9AE5-F0YA-E92G

Chen, W., and Chuang, C. (2011). Effect of varied types of collaborative learning strategies on young children: An Experimental Study. International Journal of Instructional Media, 38 (4), 351 - 358.

Eggen, P. \& Kauchack, D. 2012. Strategi dan Model Pembelajaran: Mengajar Konten dan Keterampilan berifikir. Edition $6^{\text {th }}$ translate to Indonesian Language. Jakarta: PT. Indeks.

Jalinus, N., \& Nabawi, R., A. (2018). The Instructional Media Development of Welding Practice Course Based on PjBL Model: Enhancing Student Engagement and Student Competences. Int. J. Innovation and Learning, 24 (4), $383-$ 397. doi: 10.1504/IJIL.2018.095365

Johnson, D.W. \& Johnson, R.T. (1999). Making cooperative learning work. Theory Pract, 38 (2), 67-73.

Kamdi, W. (2010). Implementasi Project Based Learning di Sekolah Menegah Kejuruan. Jurnal Pendidikan dan Pembelajaran, 17 (1), $98-112$.

Kamdi, W. (2011). Paradigma baru pendidikan teknologi dan kejuruan: kerangka pikir inovasi pembelajaran. Teknologi dan Kejuruan, 34 (1), 81-90.

Kim, K-S \&Choi, J-H. (2014). The relation between problem solving ability, professional self-concept, and critical thinking disposition of nursing students. International Journal of Bio-Science and Bi0-Technology, 6 (5), 131 - 142. doi: $10.12811 / \mathrm{kshsm} .2013 .7 .4 .105$

Lattimer, H \&Riordan, R. (2011). Project Based Learning Engages Students in Meaningful Work. Middle School Journal, 43 (2), 18-23. doi: 10.1080/00940771.2011.11461797

Lazinica, A \& Calafate, C. (2009). Technology Education and Development. Vukovar: In-Teh

Merrill, M., D., (2002). First principles of instruction. Educational Technology Research and Development, 50 (3), $43-$ 59.

Mohamed, et al. (2011). An Implementation of POPBL for analog electronics (BEL10203) course at the faculty of electrical and electronic engineering, UTHM. Journal of Technical Education and Training, 3 (2), 45-53.

Mohamed, W., A., W., \& Omar, B. (2010). Development problem solving skills for lifelong learning through workbased learning among community college student. Journal of Technical Education and Training, 2 (1), 1- 8.

Neo, M. (2004). Cooperative learning on the web: a group based, student centred learning experience in the Malaysian classroom. Australasian Journal of Educational Technology, 20 (2), 171 - 190. doi: https://doi.org/10.14742/ajet.1358

Nepal, K., P., \&Jenkins. G., A. (2011). Blending project-based learning and traditional lecture-tutorial-based teaching approaches in engineering design course. Proceedings of the 2011 AAEE conference, Fremantle, Westren Australia. 338 - 343. Retrieved on December 2017 https://research-repository.griffith.edu.au/handle/10072/46601

Ng, K.K., Wang, F. L, Luk, L. \& Kwan, R. (2016). Leveraging education of information technology in business: the application of a project-based, problem-based, and flexible learning model. Int. J. Innovation and Learning, 19 (4), 377-396. doi: 10.1504/IJIL.2016.076796

Pablos, V., B., G. \&Pozo, M., M., d. (2017). Project-based learning (PBL) through the incorporation of digital technologies: An evaluation based on the experience of serving teachers. Computer in Human Behaviour, 68, $501-$ 512. doi: 10.1016/j.chb.2016.11.056

Perez, E., Pearrocha, I., Perez, A., Serrano, J., Belenguer, E., \&Sanchis, R. (2009). Cooperative project-based learning for machine design in the Industrial Engineering Program: Methodologies and experiences. In A. Lazinica and C. Calafate (Eds.), Technology, Education and Development (pp. 395 - 414). Vukovar: In-Teh. Doi: 10.5772/7273

Prosser, C. A., \&Ouigley, T. A. (1950). Vocational Education in a Democracy. Chicago: American Tech.Society.

Saripudin, A., Haryani, S., \&Wardani, S. (2015). Characterized project based learning to improve critical thingking skill. ICMSE 2015 Proceedings (pp. 6 - 11). Retrieved on December 2017 at http://icmseunnes.com/2015/wpcontent/uploads/2016/03/46_CE.pdf

Siegel, C. (2005). Implementing a research based model of cooperative learning. The Journal of Educational Research, 98 (6), 339-349.

Smaldino, S., E., et al. (2012). Teknologi Pembelajaran dan Media Untuk Pembelajaran. Translate to Indonesian language by Arif Rahmat. 2011. Jakarta: Kencana 
Syarifuddin, A. (2011). Model Pembelajaran Cooperative Learning Tipe Jigsaw Dalam Pembelajaran. Ta'dib, 16 (2), $209-226$.

Tafakur \&Suyanto, W. (2015) Pengaruh Cooperative project-based learning terhadap motivasi dan hasil belajar praktik “Perbaikan Motor Otomotif' di SMK 1 Seyegan. Jurnal Pendidikan Vokasi, 5 (1), 117- 131.

Vila, C., et al (2017). Project-based collaborative engineering learning to develop industry 4.0 skills within a PLM framework. Manufacturing Engineering Society International Conference 2017, MESIC 2017, 28-30 June 2017, Vigo (Pontevendra), Spain. Procedia Manufacturing $13 \quad$ (2017). $\quad$ Elsevier $\quad$ Ltd, $1269 \quad-\quad 1276 . \quad$ doi: 10.1016/j.promfg.2017.09.050

Xinya, X. (2016). The Application of "Project-Based Learning" in Higher Vocational Computer Courses. 2nd International Conference on Education Technology, Management and Humanities Science (EMHS 2016). Published by Atlantis Press, 310-313.

Yeen-Ju, H., T., Mai, N. \& Selvaretnam, B. (2015). Enhancing roblem-solving skills in an authentic blended learning environment: A Malaysian Context. International Journal of Information and Educational Technology, 5 (11), $841-$ 846. doi: 10.7763/IJIET.2015.V5.623

Zhang, Z. (2013). Application of Project-Based Learning in Teaching of the Curriculum of Combining Study with work of Higher Vocational Education. International Conference on Education and Information Technology System. Published by Atlantis Press, 724-727. 